\title{
導電接着材による端子接続の高周波導通特性の実験的検証
}

\author{
大塚 寛治 ${ }^{*}$, 渡辺 伊津夫 ${ }^{* *}$, Richard H. ESTES ${ }^{* * *}$, 和田 稔 ${ }^{* * *}$
}

\section{Experimental Verification of High Frequency Conduction Characteristics of Terminal Connections by Conductive Adhesive Materials}

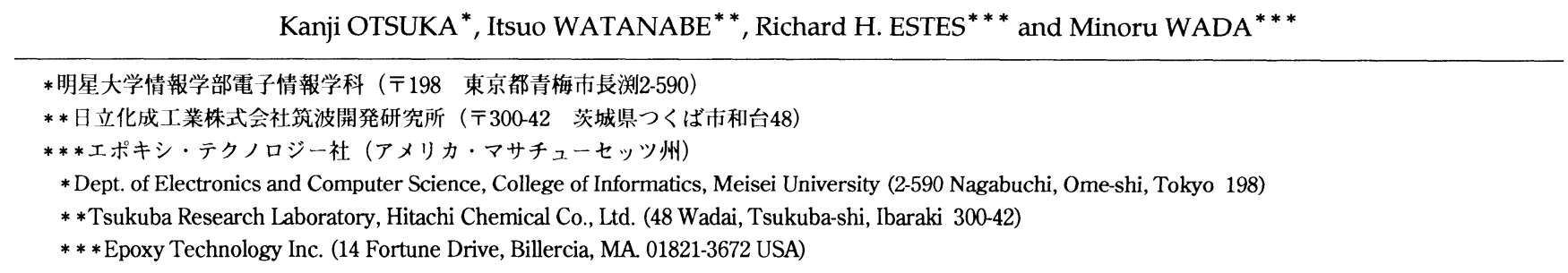

\begin{abstract}
When film or paste of an organic adhesive material, in which metallic balls or flakes of approximately $5 \mu \mathrm{m}$ in diameter have been dispersed, is used as an electrical connection material, the electrical junction is considered to be free from causing environmental pollution and capable of finer-pitch connection than the conventionally-used solder-joint electrical connections, and thus has attracted attention. In the past, dc resistance has been well verified, and its problem is thought to have been solved. However, in spite of the fact that it is the junction where high frequency pulse signals flow in real applications, its high frequency characteristics have not been verified. The purpose of this study is to make actual measurement of the transmission characteristics of high frequency pulses through this junction and verify the practicability of the connection method. Applied pulse was of $2 \mathrm{~ns}$ rise and fall time. When the peak voltage of the pulses was going down, the interconnection would be unstable in sometime, where points were measured. From this measurement data, it was found that conductive paste would show high-frequency transmission characteristics (over $100 \mathrm{MHz}$ ) that are trouble-free with respect to the connection mesh like network having distances of $50 \mu \mathrm{m}$ or so. The reason for the stability despite the large number of contacts chained together can be deduced from the action of mechanical compressive force due to the resin filling, which resulted in the stable existence of each contact as a metallic (ohmic) contact.
\end{abstract}

Key Words: Anisotropic Conductive Film, Isotropic Conductive Paste, Electrical Contact by Organic Conductive Adhesives, High Frequency Characteristics on Contacts

\section{1.はじめに}

約 $5 \mu \mathrm{m}$ 直径の金属ボールまたはフレークを有機接着剤 に分散させたフィルムまたはぺーストを電気的接続材と して使用したとき，その電気接続点は，従来一般に用い られていたはんだによる電気接続点より，無公害で微細 ピッチ接続が可能であるとして，注目されている。徐々 に実用化された例が発表されているが，信頼度上の不安 を完全に払拭されないままであり，今一つ普及の速度が 遅いのが現状である。

従来, 直流抵抗がよく確認されていて，その問題はほ ぼクリアされていると思われる占3)。しかし，実用レベル では高周波パルス信号の流れる接点であるにも関わらず， その高周波特性が確認されていない。これが普及に対す る一つの大きな不安となっている。本研究ではこの接点
に対する高周波パルスの伝送特性を実測し，この接続方 法の実用性を検証することにある。

本研究の一部の概要はすでに報告されているが4.5), 複 数の材料と構造で確認する必要があり，それを追加して， ここではそのまとめを述べる。

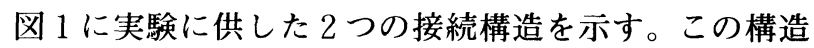
はいずれもチップをダイレクトにプリント配線板に接続 するフリップチップ構造である。その接続材料がそれぞ れ異なり，その 1 つは異方性導電フィルムを使用した。 フィルム内の分散金属ボールはニッケルボールと金めっ きプラスチックボールを使用した。いずれも平均径が 5 $\mu \mathrm{m}$ である。もう 1 つは等方性導電ぺーストを使用した。 この内容は銀フレーク分散のエポキシ樹脂である。

実験サンプル（以下テストクーポンと呼ぶ）は, 図 1 のように，プリント配線板の配線の先端にそれぞれのチ 


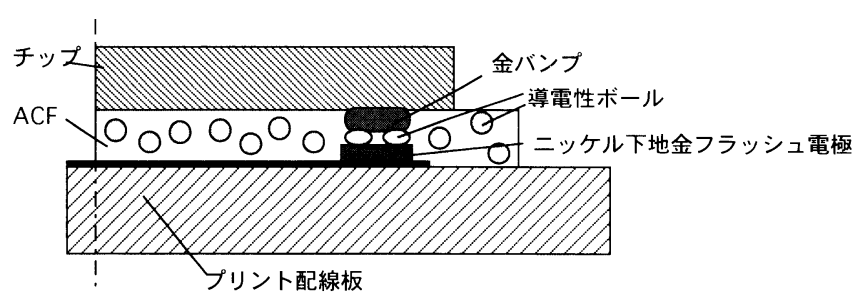

(a) 異方性導電フィルム（ACF）によるフリップチップ接続構造 アンダーフィル

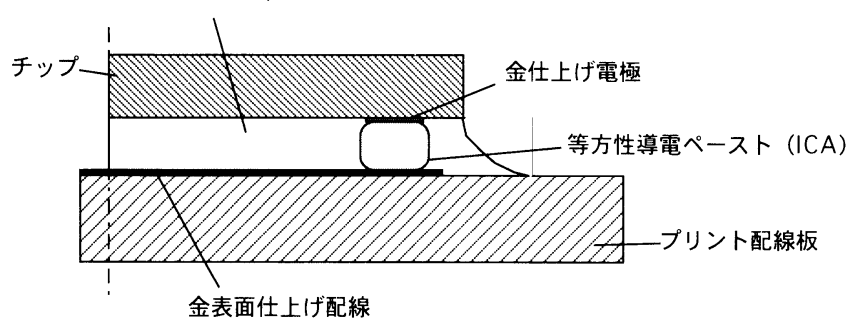

（b）等方性導電ペースト（ICA）によるフリップチップ接続構造

図1. 導電接着材によるフリップチップ接着樓造

ップ電極を導電性接続材で接続している。このテストク 一ポンのチップ側に設けられた隣接の 2 つの電極を短絡 し，コの字型の回路を作り，高周波パルスを印加して， その伝送特性をみたものである。印加電圧をどんどん下 げていくと接続部のオーミックコンタクト状態が不完全 であれば, 電圧印加時間より電流が遅延する現象，すな わち, フリッティング現象 (fritting phenomena'尚またはreignition phenomena ${ }^{7}$ と呼ばれ, コネクタ分野では一般的 に理解されている現象）が起こる。金属接触点の薄い絶 縁層や不純物層が存在すると, 通電するためには, これ を電界で破壊しなければならず，破壊電压に達するまで 電流が流れない現象である。これで電磁エネルギが乱れ るため, 電圧波形も変形する。電圧により絶縁破壊され たところはその通電中は変化がないが, 通電をやめると, 接触点金属が近づいたわけではないため，往々にして， 次回の通電時は別の接触点で同じ現象が起こる。このフ リッティング現象の有無を高周波で調べることが本研究 の目的である。

今回の実験方法はパルスのオン・オフの繰り返しによ る接点の安定性を直接的にみるものである。今まで行わ れていた一定電圧印加によるネットワークアナライザの

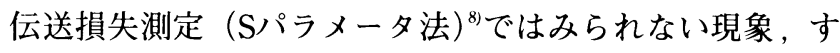
なわち, オーミックコンタクトの繰り返しパルスの安定 性をみるものである。これは過去行われておらず，本研 究が最初の試みと考えられる。非常に単純な実験である が，新しい知見が得られる可能性がある。

\section{2. 実験方法}

図 2 に本実験の測定状態を示す。(a)はテストクーポン の断面状態とそのプローブ位置を示す。信号源供給点の 内側を測定のプローブ点とした。図 2 (b)は(a)の上面図で ある。チップ内は隣接電極間に短絡配線が施され，プリ

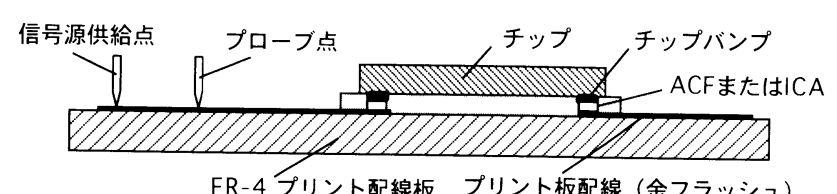

(a) テストクーポンの断面構造とプローブ位置

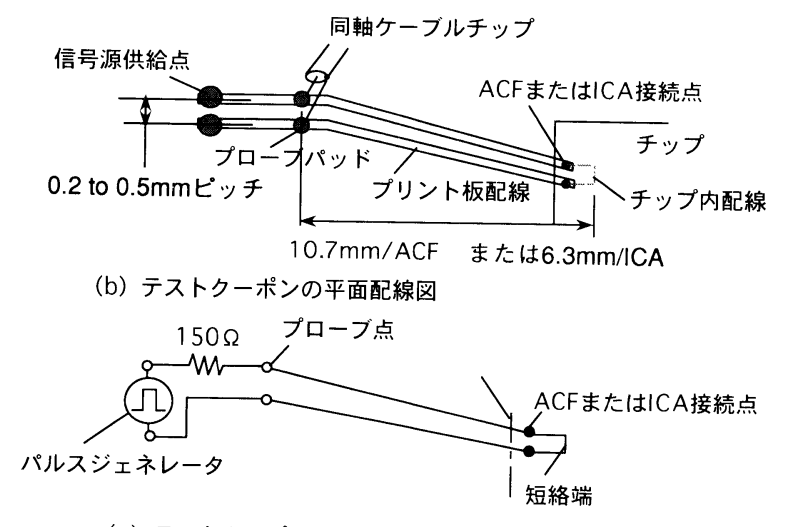

（c）テストクーポンの等価回路

\section{図2. 測定棬造を説明する図}

ント配線板の往路復路に接続されている。したがって， 測定回路には，2つの導電接着材の接続点が含まれてい ることになる。プローブ点には $1 \mathrm{M} \Omega$ のンピーダンスを 持つプローブチップを直接あて, 寄生インダクタンスの 影響をできるだけ，小さくする配慮をした。

なお，等方性導電ぺーストのクーポンはその構造から， 信号源供給点の直内を測定のプローブ点とした。チップ の短絡配線点からプローブ点までの距離は, 異方性導電 フィルムクーポン群が $10.7 \mathrm{~mm}$, 等方性導電ペーストクー ポンが $6.3 \mathrm{~mm}$ である。

図 2 (c)にその等価回路を示す。チップ側のパッドピッ チ（約 $150 \mu \mathrm{m} ）$ からプローブ点（約0.5mmピッチ）にゆる やかに広がったファンアウト構造のため, ライン幅／ス ペース幅比率の変化が少ない。これは伝送線路としての 特性インピーダンスの変化が少ないことになるため, こ のループ回路は高速伝送が可能な構造となっている。伝 送線路としてみたとき, チップ側が短絡終端となってい るため，信号は反射係数-1の全反射をする。送端の抵抗 を線路の特性インピーダンスに近づけ，その反射エネル ギを吸収する必要がある。そこで, 線路の特性インピー ダンスを $150 \Omega$ と想定して（これが主題でないため，測定

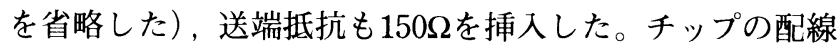
がオープンになっている回路の測定例を図 3 上に示す。 きれいな測定波形が得られているため，反射波は挿入抵 抗で吸収されていると判断できる。

$2 \mathrm{~ns}$ 立ち上がり，立ち下がり，200～250nsの保持時間 の電圧方形波を高周波パルスとして印加した。立ち上が り, 立ち下がりのレートから $80 〜 160 \mathrm{MHz}$ の周波数をシミ ュレーションしたことになる。この方形波の電圧をどん どん下げていったとき, 接続部の金属接触部が不安定で あると，伝送波形にノイズがのるはずである。パルスオ 


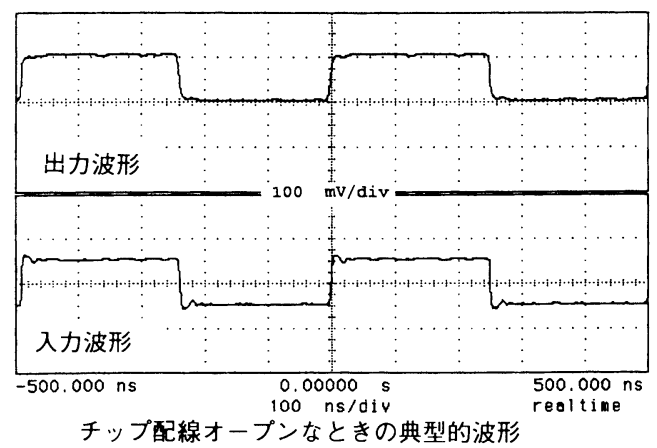

150MHzが想定できる立ち上がり時間

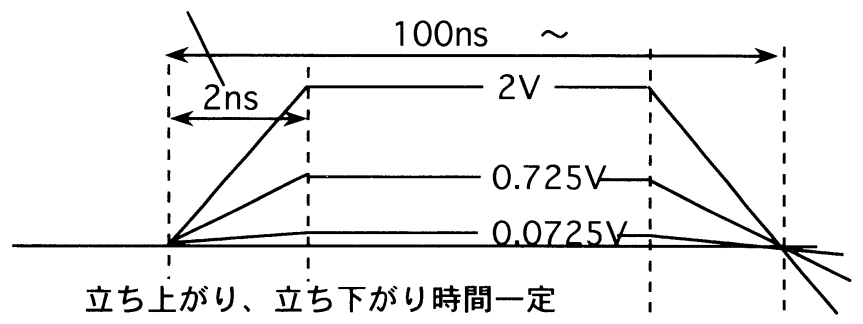

図3. 立ち上がり時間を一定とする印加パルスプロファイル

ン・オフの回数は 5 分間で $1.2 \times 10^{9} \sim 3 \times 10^{9}$ 回であり, 短 時間に膨大な回数のスイッチング安定性の確認が可能で ある。電圧が低い状態で，オン・オフを繰り返すとき， 金属接点が不安定であれば，当然，短絡端の抵抗值が変 化するため，波形変形が認められるはずである。なお， ここでは 1 つの実験の観測時間を 5 分と定めて行った。

オシロスコープはワンタイムノイズを捕捉できるよう， $1 \mathrm{GSa} / \mathrm{s}$ の 観測レートを持つ Hewlett Packard社製 54512B (300MHz)を使用した。また，信号波形を安定にす ること, 電圧を変えても図 3 下のように立ち上がり時間 を一定に保てるようプログラムパルスジェネレータ；同 社製8161Aを使用した。

導電性接着材の接触する電極の表面仕上げは，両者共 に金仕上げである。異方性導電フィルムクーポンは上下 電極共にバンプ状になっていて，この間に約 $3 \mu \mathrm{m}(\mathrm{Ni})$, 約 $5 \mu \mathrm{m}$ （Auめっき）の金属ボールが数十個のオーダで, 平面的に一層に散らばって電極間に挟み込まれている。 等方性導電ペーストは，平滑上部と下部電極間に $50 \mu \mathrm{m}$ の 厚みのバンプ状となって接続されている。

異方性導電フィルムの材料構成はエポキシ系樹脂をべ 一スにしたもので, ニッケル金属粒子を分散したもの， プラスチックボールに金めっきを施したものの 2 種類を 用いた。等方性導電ペーストの材料構成は，エポキシ樹 脂を用い，フレーク状の銀を分散したものである。これ を接続して硬化させ，その後，エポキシ系アンダーフィ ル材をすき間に充てんする。

両材料系ともにすき間に充てんされている樹脂の硬化 収縮で, 常時, 接続端に圧縮応力がかかっていて, 接触 金属部の力学的安定が図られている。

\section{3. 実験結果と考察}

3.1 異方性導電接着フィルムを使用したクーポンにつ いて

ニッケルボールを使用した異方性導電フィルムのクー ポンの測定結果を，図 4 にまとめた。印加電圧の立ち上 がり時間は測定系の寄生素子の影響で 4 nsになっている が，概略良好な方形波が得られている。測定端の電圧変 化は，パルス変化したところで大きなオーバーシュート をしている。これは短絡端の電流全反射によるスパイク であり，回路中の寄生インダクタンス，キャパシタンス による共振現象である。安定したところは回路のわずか な直流抵抗成分による微小電圧変化を示している。

各電圧の測定波形は，印加電圧が $0.725 \mathrm{~V}$ までは正常な伝 送特性を示すが，72.5mVで，図 4 (d)のように，48mVの ノイズが時々発生することが判明した。これはニッケル ボールの表面酸化物層の影響で, フリッティング電圧効 果を示した結果と考えられる。

図 5 にフリッティング現象で起こる電圧電流変化のモ デルを示す。金属接触部に介在する絶縁物や半導体の破 壊電圧に応じて，電流の立ち上がりは遅延するが，耐圧 の大きな絶縁層の破壞，すなわち電流遅延が大きいほど， 電流の立ち上がり（di/dt）は急峻である。その結果，回 路内の寄生インダクタンスLで大きなノイズ電圧 $\mathrm{v}_{\mathrm{N}}=\mathrm{L}(\mathrm{di} / \mathrm{dt})$ が発生する。この電圧が寄生キャパシタンスC とLの影響で共振を起こす（共振周波数 $\mathrm{f}=1 / 2 \pi \sqrt{\mathrm{LC}}$ )。こ の現象により，図 4 (d)のような共振ノイズとなったもの と思われる。

フリッティング現象であると確証するにはこのデータ 
(d) Ni ACF, $0.0725 \mathrm{~V}$

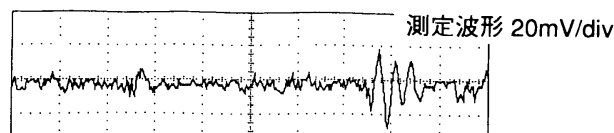

(c) Ni ACF, $0.725 \mathrm{~V}$

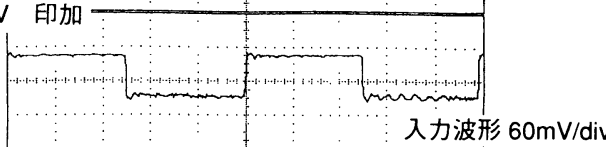

(b) Ni ACF, 1.5V

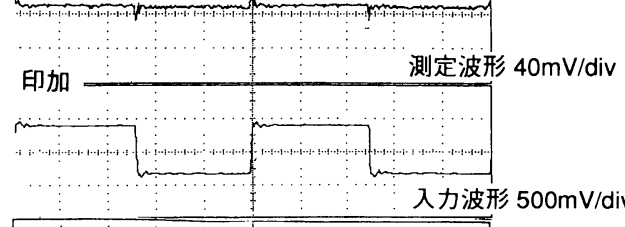

(a) Ni ACF, 4V EPta

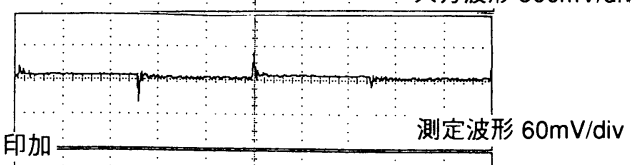

入力波形 1V/div

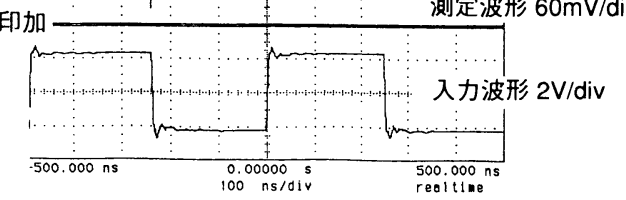

図4. ニッケル粒子の異方性導電フィルムクーポンの測定電圧 プロファイル

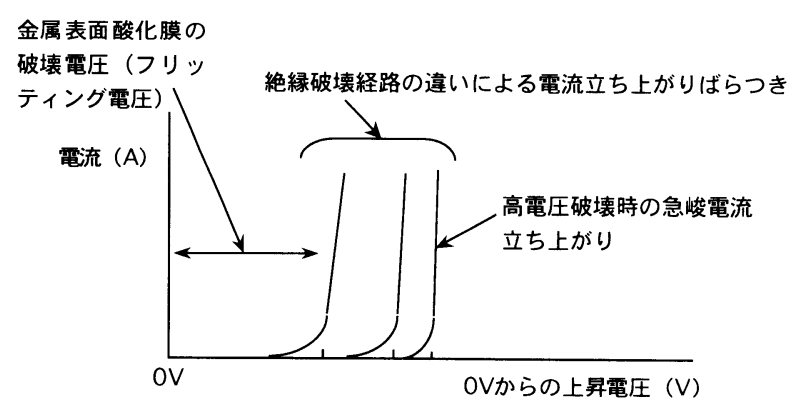

(a) フリッティンク現象を説明する電流・電圧プロファイル

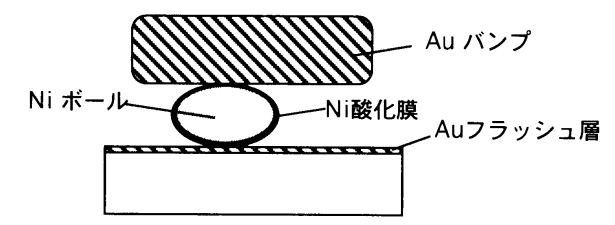

(b) フリッティンク現象の起こる条件

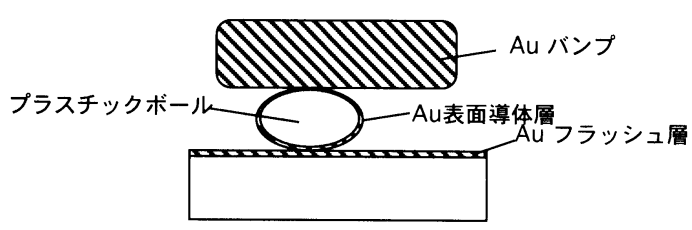

(c) フリッティンク現象の起こらない条件

図5. フリッティング現象を説明するモデル図 (a) 入力電圧波形

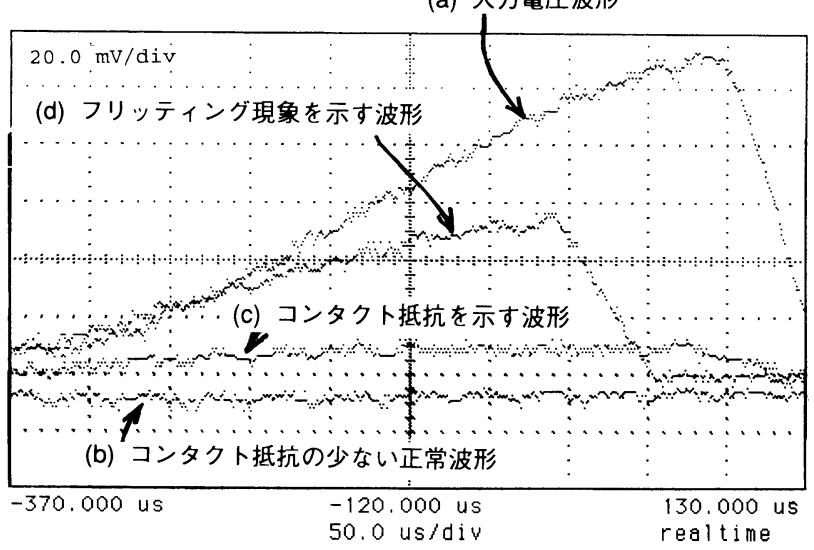

図6. Niボール入り等方導電接着フィルムクーポンのフリッテ イング現象を確認するーデータ

だけでは不足であると思われたため, ニッケルボールの クーポンについて徐々に電圧を上昇させたときのプロー ブ点の電圧を見た。これを図 6 に示す。入力電圧波形(a) でわかるように， $800 \mu \mathrm{s}$ で $110 \mathrm{mV}$ まで直線的に上昇する波 形を $5 \mathrm{~ms}$ で繰り返すものである。1クーポンの測定個所は 64個あるが，ほとんどの測定点は図 6 (b)（オフセットを 多少下げて，0レべルが重ならないようにした）のように 短絡現象を示す（正常な接続状態を示す）波形が測定点 で得られた。チップのコーナの測定点で, 波形(c)のよう に多少抵抗を示す個所を発見し，この観測を30分間続け た。30秒に 1 回ぐらいの割合で, 波形(d)（これが最大で， 大部分は(c)と(d)の中間) が現れた。これが図 5 のモデル を表す現象，すなわち，ある電圧上昇まで電流の流れな い領域を示すものと思われる。いくつかの例の記録を行 ったが，電圧の急激な降下を示さず，図 5 (a)のdi/dtの急 峻なところを立証できなかった。しかし，ある電圧に達 するまで導通がとれないというフリッティング電圧の直 接観測ができ，高周波測定での電流遅延によるオーバー シュート/アンダーシュートの可能性があると考えられ る。

また，この測定波形は全般にノイズが大きく，ニッケ ル金属接続点が不安定であることを示すと思われる。二 ッケル表面は一般に酸化膜で覆われていることから，こ の酸化膜の影響がでたものと思われる。すなわち電流パ スは一番耐圧の小さなところを選んでいるため, 通常は 多少のノイズ増大程度で収まっているが，ときどき耐圧 の大きな酸化膜の部分を選ぶことから，このノイズが観 測されることになる。雷がかならずしも最も抵抗の少な いところに落ちない現象と類似されるものである。数分 に 1 回程度の頻度で現れる。

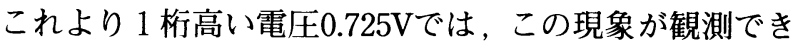
ない。この観測系で検出できないということは，現実に 問題がないということである。それはノイズレベルにも 現れていて，72.5mV印加のものより絶対值で小さくなっ 
表1. ニッケルボール異方性導電接着接続点の高周波測定結果のまとめ

\begin{tabular}{|c|c|c|c|c|c|}
\hline 実験番号 & $\begin{array}{c}\text { 入力パルス電圧 } \\
\text { (V) }\end{array}$ & $\begin{array}{c}\text { プローブ点測定電圧 } \\
(\mathrm{mVV})\end{array}$ & $\begin{array}{c}\text { 測定から導出した抵抗值 } \\
(\Omega)\end{array}$ & $\begin{array}{l}\text { オーバーシュート・ } \\
\text { アンダーシュートノイズ }\end{array}$ & $\begin{array}{l}\text { フリッティング } \\
\text { ノイズレベル }(\mathrm{mV}) \\
\end{array}$ \\
\hline (a) & 4 & 12.5 & 0.47 & 変化直後大 & 微小 \\
\hline (b) & 1.5 & 6 & 0.60 & 小 & 微小 \\
\hline (c) & 0.725 & 2.5 & 0.51 & 小 & 微小 \\
\hline (d) & 0.0725 & 微小 & $\cdots(294)$ & 全面で大 & 48 (p-to-p) \\
\hline
\end{tabular}

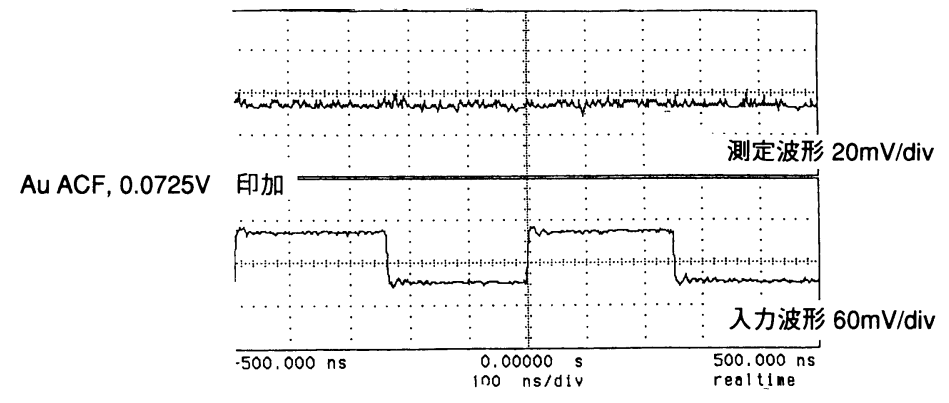

図7. 金導電性被膜プラスチックボールの異方性導電フィルムクーポンの測定電圧プロファイル

ている。したがって，3.3V電源電圧が一般的なCMOS回路 ではまったく問題がないと思われる。

ここで図 4 のデータをまとめると表 1 のようになる。 測定電圧差から回路全体の直流抵抗を計算すると約 $0.5 \Omega$ となる。直流での接続点あたりの抵抗は数ミリ $\Omega$ と測定さ れている4 ため，その差は配線の抵抗であろうと推定され る。なお $72.5 \mathrm{mV}$ 印加の平均ノイズレベルを抵抗による誘 起電圧であると予測すると, 表 1 のカッコで示した抵抗 となる。

一方，金めっきプラスチックボールでは，すべてが 金一金接続のため, 酸化膜は界面になく，図 7 に示した

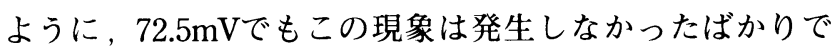
なく平均ノイズも小さなレベルで, 安定な接続点である ことがわかった（図 5 (c))。この結果と対応して, 表面酸 化物層の影響を傍証できた。繰り返すが，現状の回路の

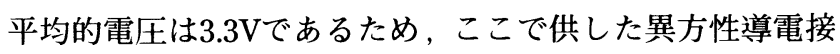
着材はいずれも問題なく高周波装置に適用できることが 判明した。

\section{2 等方性導電ペーストを使用したクーポンについて}

等方性導電ペーストのクーポンは接続系は金一銀一 銀一金系であり，これも上記金系と同様ほとんど酸化物 が介在しない。しかし銀フレークが網目状に $50 \mu \mathrm{m}$ の厚み にわたって接触する多くの接点系であるため, 違った影 響を示す可能性がある。ここでは，異方性導電フィルム クーポンの測定波形の安定化が約50nsと速かったため, パルス保持時間を250nsから100nsに速めて同様な測定を した。 5 分間のオン・オフ観測では異方性導電フィルム クーポンの 2.5 倍の安定性をみたことになる。これを図 8 に示す。

異方性導電フィルムクーポンとほとんど同様な変化を
示していて, 電圧を変えても, ニッケル接点のような不 安定ノイズがでないことが判明した。測定点のスパイク は異方性のそれとほぼ同じである。ループ回路の伝送距 離はこのクーポンの方が短く, 寄生インダクタンスとキ ヤパシタンスが小さいように思われるが，配線が細く互 いにやや離れているため, ループ回路の往路と復路のカ ップリングがやや弱い。このため寄生素子群がやや高く なり，実効的に異方性導電クーポンのそれと同じになっ て, 同じ程度のスパイク強度となったものと思われる。 これをまとめると表 2 のようになる。7 V印加で $36 \mathrm{mV} の$ 変化が現れたため, 回路の直流抵抗は $0.81 \Omega$ となる。マル

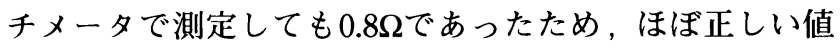
を示している。より低い電圧のときのデータから抵抗を 算出すると, やや高い傾向となっているが, 電圧の誤差 が大きくなっているため, これらの抵抗の誤差も大きい。 抵抗が異方性のそれより高い理由は, 前述のように, 配 線の幅が細く，それが効いていると思われた。

この測定データから, 等方性導電ぺーストは $50 \mu \mathrm{m}$ 程度 の距離をもつ接続網に対して, なんら問題のない高周波 伝送特性を示すことが判明した。接触点が多数連鎖して いるにもかかわらず安定な理由は充てん樹脂による力学 的圧縮力が働いていて，それぞれの接触点が金属接続 （オーミックコンタクト）として安定に存在するからと推 測できる。

\section{4. 結 言}

導電性樹脂接続材料を使用したフリップチップ型接続 端子の高速パルススイッチングの安定性を，実験的に観 測した。そのデータから；

（1）ニッケル粒子を接点とする導電性接続材（ニッケ 


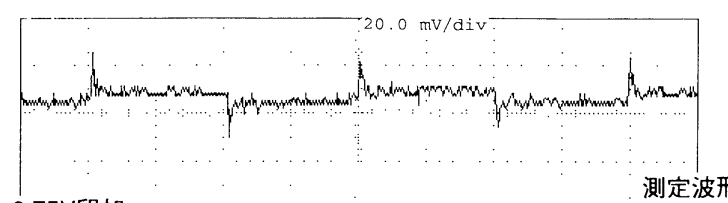

(c) $0.75 \mathrm{VE}$ 印加 測定波形

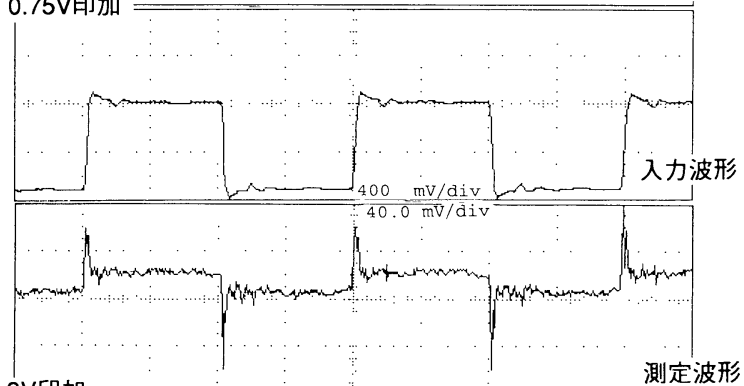

(b) 3V印加

測定波形

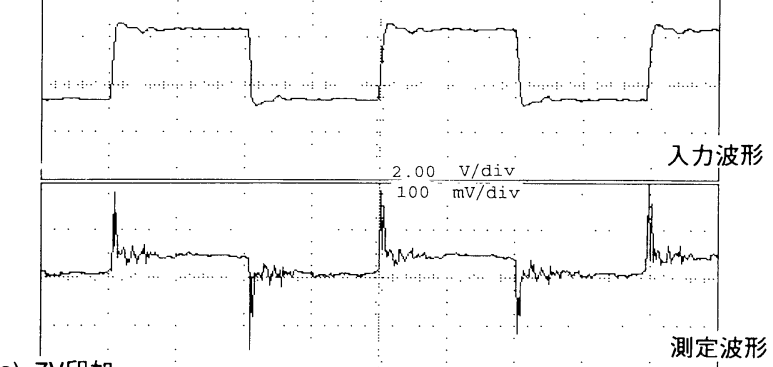

(a)

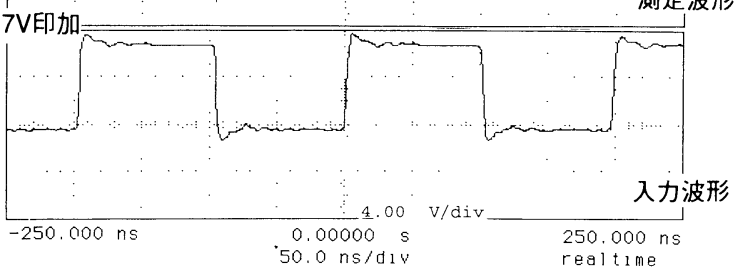

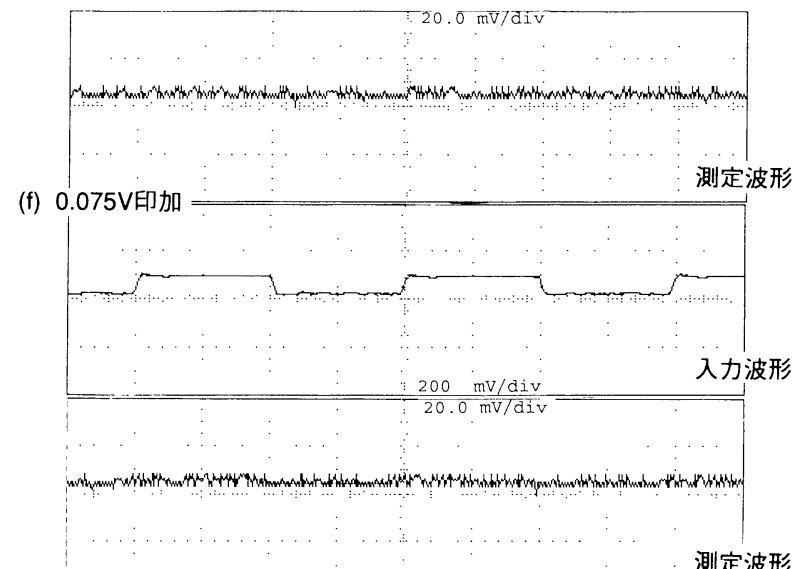

(e)

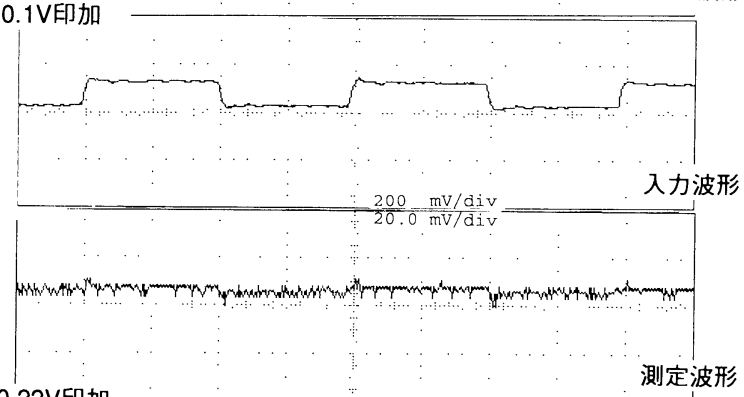

(d)

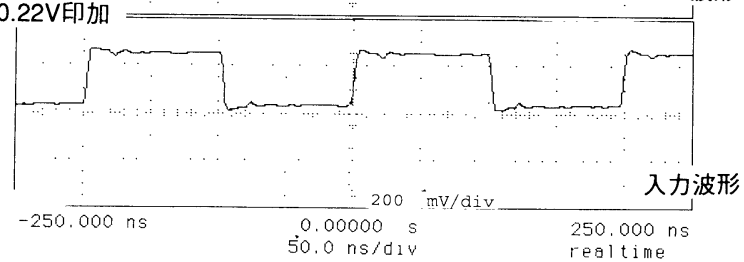

図8. 等方性導電ペースト（銀ペースト）テストクーポンの測定電圧プロファイル

表2. 等方性導電ペースト仕様クーポンの測定電圧のまとめ

\begin{tabular}{|c|c|c|c|c|}
\hline クーポン番号 & 印加電圧 & 測定電圧 & 計算抵抗 & \multirow[t]{2}{*}{ 出力波形のノイズ } \\
\hline 単位 & $\mathrm{V}$ & $\mathrm{mV}$ & $\Omega$ & \\
\hline (a) & 7 & 36 & 0.81 & 初期スパイク大, 安定波形はノイズ小さい \\
\hline (b) & 4.5 & 27.3 & 0.91 & \multirow{5}{*}{$\begin{array}{l}\text { 初期スパイク徐々に低下, } \\
\text { 安定波形はノズさい }\end{array}$} \\
\hline (c) & 3 & 15.6 & 0.79 & \\
\hline (d) & 1.75 & 8.36 & 0.72 & \\
\hline (e) & 0.75 & 3.64 & 0.73 & \\
\hline (f) & 0.4 & 2.30 & 0.89 & \\
\hline (g) & 0.22 & 1.82 & 1.25 & \multirow[t]{4}{*}{ ノイズが小さく安定 } \\
\hline (h) & 0.15 & 1.27 & 1.28 & \\
\hline (i) & 0.1 & 0.91 & 1.38 & \\
\hline (j) & 0.075 & - & - & \\
\hline
\end{tabular}

ルー金系) は，非常に低い電圧（0.07V程度）でニッケル の表面酸化が原因と思われるフリッティング現象が観察 され，印加電圧に近いノイズが観測された。

(2) 金一金接続系, 金一銀連鎖型接続系ではニッケル 接続系のようなフリッティング現象は観測されず安定な 高周波特性を得た。

(3) ニッケル系でも0.7Vより上の電圧印加ではフリッテ イング現象を示さず, $3.3 \mathrm{~V}$ 系電子回路ではなんら問題のな
いことが確かめられた。

これらの事実は，はんだ接続代替技術の普及を加速す る実験事実として，世の中に貢献するものと思われる。

導電接着羭は, 直流抵抗をパラメータとして環境安定 性（信頼性）がすでに確かめられている吕3)。ほとんど問 題のないデータが多く発表されているが，多少でも抵抗 值が増大方向に劣化しているデータが多い。高周波特性 では, この問題がより顕著に現れ，フリッティング電圧 
の増大方向となるかも知れない。残された課題である。

なお，こんぺい糖のような形をしたニッケル粒子を異 方性導電フィルムに混入した製品 ${ }^{9}$ ，同じく異方性導電ぺ 一スト材 ${ }^{10)}$ が発表され, その直流の信頼度データはニッケ ルボールより安定な状態を表している。こんぺい糖の笑 起が金の電極に食い込み, 酸化膜が破れ, 安定な金属接 続を保っている可能性がある。これら材料は本研究のよ うにフリッティング現象を示さない可能性がある。この 測定も今後の課題としたい。

さらに電極表面が貴金属でないか，導電接着剈の金属 がはんだなどの材料のときは直流の信頼度データもよく ないことが発表されている11。フリッティング電圧が実用 電圧と等価になったためではないかと想像する。もしこ れを実用化するためには，金属の塑性変形を起こさせ， 酸化膜を破るプロセスが必要な気がする。この分野では コネクタやソケットの考え方が手本となると思われる。

\section{5. その他}

テストクーポンの構造やプロセスに関してはノウハウ の関係で記述を避けた。これら仕様に関する問い合わせ は直接クーポン提供者に連絡いただきたい。下記に連絡 先を示す。

- 日立化成工業(株)筑波開発研究所, 渡辺伊津夫氏

（テ300-42，つくば市和台48）Fax. 0298-64-4008

- EpoTech. 和田 稔氏 (14 Fortune Drive, Billercia, MA 01821-3672 USA）Fax. (508) 633-9782

(1997.6.2-受理１997.10.23-再受理）

\section{文献}

1) I. Watanabe, et al. : "Flip-Chip Interconnection to Various Substrates Using Anisotropic Conductive Adhesive Film", Journal of Electronics Manufacturing, Vol.5, No.4, pp.273276, (1995)

2) K. Kusagaya, H. Kira, K. Tsunoi : "Flip Chip Mounting Using Stud Bumps and Adhesives for Encapsulation”, Proceedings of International Conference on Multichip Modules, pp.587-
595, (1993)

3) B. Viertl, B. Rosner : "Flip Chip with Polymer Bumps on Various Substrates", Proceedings of First International Conference on Adhesives in Electronics, Berlin, (1994)

4) K. Otsuka, I. Watanabe, K. Takemura : "High Frequency Characterization of Conductive Adhesive and Its Interconnection Technology", Proceedings of Adhesive in Electronics '96, pp.114-125, 1996.6

5) K. Otsuka, I. Watanabe, K. Takemura : "High Frequency Characterization of Conductive Adhesive", Extended Abstract of Third VLSI Packaging Workshop of Japan, pp.87-91, 1996.12

6) Gizella Kovacs : "Failure Analysis of Contaminated GoldPlated Connector Contacts from Operating Communication Equipment", IEEE Trans. CHMT, Vol.5, No.1, pp.95-101, (1982)

7) Manfred Lindmayer, Ernst-Dieter Wilkening, "The Influence of Circuit Parameters and Contact Materials on the Re-ignition of High Frequency Vacuum Arcs", IEEE Trans. CHMT, Vol.13, No.1, pp.69-73, (1990)

8) C. E. Abernethy, A. C. Cangellaris, J. L. Prince : "A Novel Method of Measuring Microelectronic Interconnect Transmission Line Parameters and Discontinuity Equivalent Electrical Parameters Using Multiple Reflections", Proceedings of 45th ECTC, pp.329-342, (1995)

9）太田共久：“異方導電フィルム”, プリント回路学会, 先進 実装研究部会報告, 接続の低温化とソルダレスボンディン グ, pp.59-62, (1993.7)

10) T. Komukai, M. Miyazaki, Y. Samejima : "An Approach to the Anisotropic Conductive Adhesives for Micro-Interconnection Technology", Proceedings of Surface Mount International, pp.402-407, (1996.12)

11) M. Zwolinski, et al. : "Electrically Conductive Adhesives for Surface Mount Solder Replacement”, ibid, pp.391-401, (1996.12) 